\title{
Geographies of Peak Oil: the other carbon problem
}

Gavin Bridge, University of Manchester

Editorial Introduction for Peak Oil Themed Issue of Geoforum

The final version of this draft appeared as

"Geographies of peak oil: the other carbon problem." Geoforum 41, no. 4(2010): 523-530.

gavin.bridge@manchester.ac.uk 


\section{Geographies of Peak Oil: the other carbon problem}

\section{Gavin Bridge, University of Manchester}

The twin concerns of 'energy security' and 'climate change' now increasingly frame the space in which environmental futures will be worked out. Issues of energy availability and the vulnerability of fuel supplies have assumed new political prominence, so that hoary questions about depletion and scarcity now share space on environment and development agendas with greenhouse gas emissions and atmospheric pollution. But for industrial societies with a high dependence on fossil fuels, climate change and the security of energy supplies present rather different sorts of challenges. When it comes to the accumulation of greenhouse gases in the atmosphere, the 'carbon problem' is principally one of abundance and unrestrained flow - the mobilisation of lithospheric stocks of carbon via combustion. When it comes to the security of fossil fuel supplies, however, the 'carbon problem' takes the form of flow constrictions and resource constraints - the prospect of interruptions in supply and/or permanent shortfalls in availability. Climate change and energy security, then, are the yin and yang of a high-energy, fossil fuel society: two apparently contrary elements - abundance and scarcity - that are nonetheless connected through their shared relationship to a carbon-intensive mode of existence.

Questions about the security of energy supplies are, of course, much more expansive than fossil fuels alone (Lovell et al. 2009, Bridge 2010; Lee 2010, Upham 2010). This theme issue, however, centres on a contentious and unresolved claim about the depletion of global oil stocks: 'peak oil'. Peak oil refers to an impending, permanent decline in the production of so-called 'conventional' oil as geophysical limits on its availability begin to bite. Conventional crude oil refers to the highquality, easily-flowing hydrocarbons that have extensively permeated social and economic life over the last century. Providing the bulk of the world's liquid fuels, conventional crudes underpin the mobility of people and goods in the form of kerosene jet fuels, gasoline and diesel for rail and road haulage, and the bunker fuels that power ocean trade. In the last few years, concern about oil depletion has begun to appear in debates over energy security and the shape of a post-carbon future. In Australia, for example, the issue of 'oil vulnerability' has gained substantial political traction, around the possibility that limits on the availability of liquid hydrocarbons might transmit powerful shocks to urban areas (Dodson and Sipe 2007). In the United States, a series of government reports have noted the risks of peak oil for U.S. fuel supply and advised the need for concerted action ahead of any global peak (Hirsch Report 2005, GAO 2007). But the vulnerabilities and insecurities associated with the prospect of global oil depletion go beyond transportation. A sustained rise in the price of oil would call into question its use as a fuel to pump groundwater and to underpin massive productivity gains in agriculture, with significant implications for crop yields, the availability of water, and established patterns of agricultural 
production (Pfeiffer 2006, Manning 2004). The centrality of oil to modern warfighting - the U.S. military, for example, consumes about the same amount of oil as a national economy the size of Greece (Karbuz 2006) - has pushed peak oil onto the strategic radar of military establishments. A study for the Pentagon, for example, found that the post-Cold War transformation of the U.S. military into a globally mobile force capable of rapid deployment had dramatically increased its energy intensity to the point that there was an 'operational disconnect' with global energy supply (Crowley et al. 2007, Klare 2007; see also Westervelt and Fournier 2005). The centrality of cheap conventional oil to modern ways of life - and the economic and political dependencies that have been built around it - have ensured that the prospect of peaking and depletion have garnered considerable international attention. Together with climate change, peak oil has emerged as a recurring storyline in public debates through which a post-carbon future is being slowly imagined.

To this point, however, geographers have engaged peak oil in only a limited way and their contribution to the broader public debate over its economic, social and political implications has been modest. The objective of this theme issue is to map the outlines of an emerging geographical contribution to the popular and public-policy debates surrounding peak oil. It brings together seven papers that examine the discourses of finitude, urgency and security associated with peak oil, unpack the rationalities and calculative practices through which peak oil is constituted, and analyse the strategic practices and spaces to which it can give rise. In taking distinctive, theoretically-informed 'cuts' at a common object of analysis (peak oil), the papers reflect some of the epistemological diversity that is a hallmark of contemporary human geography. The collection of papers has its origins in a paper session we convened at the 2008 Annual Meeting of the Association of American Geographers which was held in Boston, an event that coincided with a period of historically high prices for oil and many other bulk commodities. It includes work first presented in that session (Hemmingsen 2010, Kristoffersen and Young 2010, Bridge \& Wood 2010), together with papers from other researchers who have begun to engage with peak oil (Labban 2010, North 2010, Bailey et al. 2010; the paper by Ian Bailey and colleagues incorporates commentary made as a discussant in the original session).

The remainder of this editorial introduction is divided into three sections. First, it provides a concise account of the 'peak oil' claim, identifying the key protagonists in the debate, and outlining different stances with regard to the timing, shape and composition (conventional vs. non-conventional hydrocarbons) of the peak. Second, after briefly characterising the limited engagement with peak oil by human geographers, it offers a provisional set of claims about what a geographical analysis of peak oil might yield. Finally, it introduces each of the papers and, in 
doing so, makes the case for a fuller and more sustained engagement by geography with this 'other carbon problem.'

\section{Global Oil Depletion: peak production and resource constraints}

Resource depletion is simultaneously a visceral, material concern and a philosophical abstraction: not surprising, then, that it is one of a handful of fundamental questions that societies have asked about themselves and their environment down the ages (Glacken 1967). The 'age of oil' is just over a century old, if one takes the discovery of abundant, free-flowing, low cost sources at Spindletop in Texas in January 1901 as the moment at which the human relationship to crude oil profoundly changed (Yergin 1992, McNeill 2000, Smil 2005). Yet within that short time, oil has come to supply over $35 \%$ of the world's primary energy needs and over $80 \%$ of transportation fuels. The scale of contemporary oil use is staggering: 1000 barrels a second, 83 million barrels a day, 30 billion barrels a year (UKERC 2009a). Given the dominance that oil has assumed and the forms of dependency it has produced, it should come as no surprise that global oil depletion has been predicted several times before. The USGS predicted in 1919 that domestic oil resources which at the time supplied a large proportion of the world's oil needs - would be depleted within a decade, precipitating an 'oil panic' that drove the opening of the federal lands for oil development (the Mineral Leasing Act of 1920) (USGS no date). In the early 1970s, the Club of Rome report on the Limits to Growth claimed that global oil reserves would run dry within 2030 years. Such episodic crises over oil's availability cast a long shadow over contemporary claims for global oil depletion. The long view is particularly attractive to peak oil's detractors, who point out how "this is the fifth time that the world is said to be running out of oil" and such "cycles of hysteria followed by new bonanzas have continued to the present" (Daniel Yergin, cited in CERA 2006; Maugeri 2004).

\subsection{Anorak off, into public view}

Concern over the prospect of global oil depletion may have historical roots but it is only since the early 2000s that its specific formulation as peak oil has gained public recognition. Rising oil prices after 2003, buoyant demand and notable production declines in established basins like the North Sea suggested to some observers the emergence of a potential 'supply gap' for oil within the next couple of decades (UKERC 2009a). The articulation of these concerns by some market analysts (e.g. Deutsche Bank 2004) and the publication of several non-specialist books about peak oil by industry experts eased a closeted concern - one previously limited to a small number of specialists within the Association for the Study of Peak Oil (ASPO) $)^{1}$ - into wider circulation 
(Deffeyes 2001, 2005, Goodstein 2004, Campbell 2005, Simmons 2005). At the same time, several writers and journalists warmed to the theme, combining peak oil's specific, geophysical claims with a more general critique of the dependency of industrial societies on petroleum and the necessary emergence of a 'new energy order' (Heinberg 2003, Roberts 2004, National Geographic 2004; see also Ruppert 2004, Kunstler 2005, Clarke 2007, Strahan 2007, Hopkins 2008, Maas 2009). The consistency of peak oil's basic premise about tightening supply with the daily experience of rising gas prices meant the topic and its proponents gained significant air time and column inches in the period from 2004 until the downturn in prices in 2008: CNN's frequent coverage in this period, for example, showcased work by ASPO (CNN 2003, 2004, 2007; see also New York Times 2006).

Prominent support for peak oil by several 'mainstream' figures - investment banker Matthew Simmons (2005), oil tycoon T. Boone Pickens, and senior public officials like the former (and first) U.S. Secretary for Energy, James Schlesinger - has made it hard to pigeonhole or sideline as either an 'academic' or 'environmental' story. The appeal of peak oil as a media story lies, in part, in the ease with which it can move back and forth between the widely different registers of daily life (the cost of gasoline) and imagined planetary apocalypse. Also, the enormity of the shifts that would be required to accommodate a 'post-peak' world of depletion contrast sharply with the implausibility of such a world at the very moment when more oil is being produced than ever before: "the resource-limited production peak...occurs when there are still large reserves in the ground, when technology and enterprise are expected to raise the recovery rate of these reserves, when new finds are still occurring, and when there is known to be quite a lot of oil yet to discover" (Meng and Bentley 2008: 1183). This "counter-intuitive" character to peak oil enables its proponents to position themselves as modern day Cassandras, seers of truth whose warnings of calamity go mocked and unheeded.

Significantly, then, peak oil has become more than an anorak's interest. A technical debate about the inflection point on a curve has become re-imagined as a critical socio-political threshold, even a turning point in the history of civilization. Peak oil has rapidly attained the status of a cultural meme, a melange of claims, representations and facts reproducing horizontally through society via repetition in traditional and electronic media. In particular, peak oil has become popularly associated with a wide variety of post-normal imaginaries that include apocalyptic societal collapse, the demise and rejection of 'carbon capitalism,' and radical forms of re-localisation and de-carbonisation as alternatives to hyperglobalisation. 


\subsection{Peak basics}

As an empirical phenomenon, the moment of maximum production can only be known with hindsight. Projections of a future peak, therefore, are either based on a model of hydrocarbon discovery and depletion or calculated directly from production and discovery trends (Meng and Bentley 2008). The method of direct calculation has attracted a good deal of recent attention, but the core model associated with peaking has its roots in calculations undertaken by Marion King Hubbert, a geologist working for Shell in the 1950s. Hubbert worked for Shell at a time when many of the world's giant oil fields were being discovered, a time in which a far greater amount of oil was being added to global reserves each year through exploration and the adoption of lower-cost production techniques than consumed through production. In the United States where Hubbert was working, oil output continued to exceed consumption by a wide margin so that the U.S. retained its role as a major exporter. Yet in the midst of these years of plenty, Hubbert sought to determine for how long U.S. oil production would continue to grow. Using a series of "educated guesses" about the size of ultimately recoverable reserves and drawing on historical data for the rate of oil discovery, Hubbert concluded that the volume of oil produced over time in a given region will tend towards a bell-shaped distribution. Production would peak, in other words, when around half of the total recoverable oil has been extracted (Deffeyes 2001). To the scorn and disbelief of many in the industry, Hubbert predicted in 1956 that U.S. oil output would peak in the 1970s. When the Texas Railroad Commission ${ }^{2}$ announced in 1971 that the U.S. was pumping oil at full tilt and there was no additional capacity that could be brought on stream to counteract rising prices, Hubbert's legacy was assured: U.S. oil production had peaked, pretty much when he had said it would (Deffeyes 2001). From then on, domestic supplies could not be expanded to keep pace with growing demand and the U.S. became a net oil importer, a transition that changed its relationship with much of the rest of the world.

Since then Hubbert's basic model has been adapted to a range of different settings and its assumption of a symmetric curve has been relaxed. ${ }^{3}$ Other methods of calculation have been introduced that do not use Hubbert's model but draw on historical field data. The core figure of a production peak flanked by rising and falling limbs has remained resilient, however and this characteristic pattern has now been observed for individual fields and for national and regional scales of analysis. Fundamentally, peaking is driven by three factors: the distribution of field size (skewed, so that a small number of very large fields account for the bulk of production); the geophysical performance of oil reservoirs (exponential pressure loss over time); and the timing of large and small discoveries (large reserves tend to be found first) (UKERC 2009a; Meng and Bentley 2008). The net effect of these three factors is that, after initial discovery, production will grow at an increasing rate as the largest reservoirs are found and brought into development. Over 
time, the rate of production begins to slow until a maximum level of output is reached. After this, the overall volume each year falls as the rate and size of successive discoveries are insufficient to replace current production and existing fields move into decline.

\subsection{Debating the peak}

Peak oil is a contentious proposition and, until recently, discussion has been highly polarised. Although there is agreement that conventional oil production will peak at some point in the future, there are substantial differences of opinion over (a) the timing of the peak; (b) the significance of a peak in conventional oil for the availability of liquid fuels; and (c) the role of supply-side restrictions in driving peak production, given the possibilities for demand destruction via technological shifts (e.g. electric vehicles) and/or political action around climate change (Lohmann 2009). Debates over timing revolve around the measurement of depletion and the uncertainties attached to existing data. The absence of "a reliable gauge" for oil depletion reflects not only the general difficulties - and historical disputes - associated with estimating mineral resources, but also the "inconsistent definitions of relevant variables, the paucity of reliable data (and) the frequent absence of third-party auditing...” (UKERC 2009a: 15). ASPO has estimated that conventional production will peak in 2010, although this is one of several estimates it has released for the peaking over the last few years and all of which have been very close to the present. More optimistic scenarios put the date at 2037 or beyond (USGS 2000).

Disagreement over the reliability and meaning of three kinds of data explain these different positions. The first of these are data relating to production trends and, in particular, to observed declines in the rate of output at some of the world's major oil fields. The bulk of the world's oil comes from a relatively small number of very large fields: $50 \%$ of global output comes from only 100 of the world's 70,000 oil fields, and the leading 25 fields represent one quarter of current production (UKERC 2009a). A meta-study undertaken by the UK Energy Research Centre (2009a, 2009b: 21) found the average rate of decline from currently producing fields to be $4 \%$ per year and $6.5 \%$ for major fields that are past their peak: to maintain current output, around 3 million new barrels of oil per day need to be brought into production each year. Pessimists interpret recorded declines as evidence that geophysical limits have finally been met and that critical fields are now in terminal decline. The starting point for the analysis by Simmons (2005) and Roberts (2005) of the 'twilight years' of oil, for example, is the falling rate of output from Saudi Arabia's Ghawar field and the increasing proportion of water in the liquid that comes to the surface. With decline curves as evidence, proponents of peak oil argue that over 60 countries have now either reached or moved past the peak, including large producers such as the United States, the UK, Norway and Indonesia (Meng and Bentley 2008; see also Strahan 2010). More 
optimistic scenarios tend to interpret decline curves as a function of investment rather than geology, and emphasise the capacity of new technology and development to lift production and turn fields around (Lynch 2009, Maugeri 2004, Yergin 2009). Others discount production declines, arguing that because reserves to production ratios remain relatively constant (around 40 years) the "normal economic process of stock renewal is working effectively" (Odell 2009: 15)..

The argument for peaking as a result of resource-constraints also hinges on data about discovery trends. These show an apparent slowdown in rate at which new fields are being found and, in particular, a failure to find new 'super-giants' like Ghawar and Burgan (Kuwait) that currently provide the bulk of the world's oil. 'Peak discovery' appears to have occurred in the 1960s and, while there have been many new discoveries since then, they have been neither as big as in the previous period nor had such large rates of flow. The result is a widening gap between discovery and production, which advocates of peak oil interpret as evidence of increasingly severe constraint on the availability of conventional oil. Detractors, on the other hand, discount 'discovery' data as being misleading because they emphasise exploration at the expense of development work to expand reserves at operating fields: CERA (2006), for example, claims that revisions, additions and new exploration have grown resources by a third more than total production since 1995. Other detractors interpret the observed fall in the rate of discovery as a function of a changing oil industry structure since the 1960s: lower rates of discovery are symptomatic of the increasing role of large reserve-holding state oil companies and the growing proportion of the world that has become 'off-limits' to leading edge technology and the competitive exploration strategies of international oil firms.

The third kind of data around which the debate over peak oil has revolved concern estimates of the size of ultimate recoverable reserves. These figures are particularly troublesome to calculate with any certainty because large areas of the earth's surface have not been explored or studied in detail. Although petroleum exploration is a relatively mature industrial sector, the intensity of exploration varies widely across space: North America, for example, is the most intensely explored while large parts of Asia, Africa and the ocean are comparatively unknown. Estimates of ultimate recoverable reserves remaining range from a conservative figure of 1 trillion barrels (Campbell 2005) to over 3 trillion barrels (USGS 2000). However, the history of estimating recoverable reserves only confirms the illusory nature of hard numbers: global reserves have been revised dramatically upwards over time as a function of additional exploration and the deployment of new technology. In practice, the uncertainties inherent to data on rates of decline, rates of discovery and the volume of ultimate recoverable reserves lead to differences of opinion about how much the rate of crude output can be increased. Optimistic projections see a future in which the current daily output of 83 million barrels can be expanded to over 100 million barrels 
per day and maintained: Cambridge Energy Research Associates, for example, estimated in 2007 that production capacity would climb to 112 million barrels per day in 2017. A larger number of informed observers, however, have expressed doubt about whether even the 100 million barrel level can be reached for conventional crude.

\subsection{Debate over 'peaking' evolves}

Differences of opinion about the size of ultimate recoverable reserves and the timing of the peak have been at the heart of debate over peak oil. They are not, however, the only reasons for disagreement or even the most important. Discussion of peak oil has evolved in the last few years in two significant ways. First, an increasing recognition that non-conventional sources of oil and conventional oil in unconventional places (deepwater, Arctic) - are already beginning to substitute for declining conventional sources. Because oil is not an homogenous material, "extracting oil from the ground is not like extracting beer from a refrigerator. Barrels are not all the same..." (Bardi 2009: 324). Running counter to the depletion of conventional oil is the possibility to push further down the 'resource pyramid,' away from the historic reliance on highquality, low cost conventional oils towards lower-quality, higher cost non-conventional sources for which estimated global reserves are significantly higher (McCabe 1998). The availability of liquid fuels from Alberta's tar sands or heavy oils in the Orinoco Delta, for example, indicate how a decline in conventional crude may be less of a constraint on the overall supply of liquid fuels than first imagined by peak oil. Any shift towards unconventional sources - and unconventional places - also powerfully illustrates something else: far from an "end to the age of oil" and an ineluctable slide towards a post-oil future down peak oil's recessionary limb, the foreseeable future is likely to be dominated by an intensification of oil extraction, through a series of massive investments to bring unconventional oil reserves into production and extend the peak. Debate over peak oil has moved on from comparatively narrow technical concerns about reserve calculation to consideration of the opportunities - and the social and environmental costs associated with unconventional sources. The alternative imaginary of a 'plateau' rather than a peak has gained ground in the last few years, both a symptom of this shift in thinking and an important reminder of the intensity of investment and extractive activity needed to feed the world's appetite for liquid hydrocarbons.

Second, falling demand for oil in OECD economies since 2005 has encouraged the counterproposition of 'peak demand' to step into the ring (Lohmann 2009, Geman 2009). While the geography of global oil demand is undergoing significant shifts, the evidence from core industrial market economies indicates that demand for oil - and for transportation fuels in particular - may have peaked, even before the effects of recession post-2008 are taken into effect. The experience 
of recession and an overall slackening of demand, however, have created a space to challenge assumptions about the strength and permanence of demand for oil. Market saturation, improved efficiency, fuel switching and emerging regulation for greenhouse gas emissions are among current drivers of demand destruction. Increased regulation of emissions and/or a greater penetration of electrically-powered transportation options may accelerate this process. The prospect that peak production may occur via a demand-side mechanism rather than supply is now being taken seriously by major oil exporters. The combined effect of these two shifts has been to place the question of supply shortages within a broader social and political context. By drawing the debate over peak oil into the realm of political choices rather than geophysical constraints, a space has been opened into which questions of need, value and justice may be introduced.

\section{Why 'geographies of peak oil'?}

In one sense, the detailed field-by-field studies of production trends conducted by the IEA (2008) that currently inform thinking about peak and plateau constitute 'a geography' of peak oil. Spatial inventories have largely replaced Hubbert's mathematical model as the technique of choice for predicting the pattern of global oil production, so that assessments of depletion are now mostly based on the aggregation of various geographies. This understanding of geography as a set of regional units whose attributes may be measured, defined and compared by reference to a set of common criteria has long been the modus operandii of resource management, and the processes of categorisation and 'statistical picturing' on which it depends should not be underestimated (Demeritt 2001; Barry 2008). However, it is not to this sense of geography that the theme issue aspires. Rather, its interest in 'geographies' lies in how geographical perspectives can be brought to bear on peak oil, in order to take on/take apart/take further one of the most interesting and problematic 'public' debates of the contemporary period. The plurality of 'geographies' is appropriate here, because of a hope that the closeted and technical character of the peak oil debate may be fractured and broken open in some interesting ways by engaging with perspectives from human geography. Nonetheless, it is a plurality constrained at its outer limits by a common understanding of peak oil as a socio-political problematic with roots in historical patterns of resource production-consumption. The purpose of this brief section, then, is to lay out a set of preliminary propositions regarding peak oil as a research agenda within critical human geography before turning to the specific papers in this theme issue.

First and foremost, peak oil is a proposition about a state of crisis in political-ecological relations. It forms one of a handful of core storylines in a broader popular discourse about resource security and environmental constraint in the $21^{\text {st }}$ century, and at a time when established patterns 
of international trade and investment in oil are changing. As for a range of resources, the claim that 'natural limits' set the bounds on oil's availability raises the spectre of (Malthusian) scarcity and the prospect of inter-imperial conflict over remaining resources. Such arguments are grist to the mill for a critical resource geography that, over the years, has adopted a strongly antinaturalist stance towards ecological limits and resource constraints (Harvey 1974, Bakker 2000, Mommer 2002, Swyngedouw 2004, Retort 2005). This work examines how the critical limits to availability often do not lie within biophysical systems, but in the organisation of production and consumption relations. There are many aspects to this in relation to peak oil, but one can begin by querying some of the assumptions about future demand which underlie the supposed 'gap' between supply and demand: it is this gap that defines a Malthusian future, and which creates the sense of necessity and inevitability often associated with the politics of peak oil.

Second, the technical debate over peak oil exposes in an interesting way how 'oil reserves' are far from stable objects. Not only are figures on national reserves political instruments in the sense that they are strategic projections (as illustrated by the large inflation of reserves among OPEC producers in the mid-1980s); they are also artefacts of the scientific and technical networks that constitute them and within which they continue to be embedded (Barry 2008). Oil reserves occupy a curiously unstable position given that they central the debate over peak oil: while they purport to describe a fixed quantity of material, their calculation occurs at the intersection of geology and economics, because the boundary that separates (economic) reserves from (uneconomic) resources is based on assumptions about price and the cost of extraction. While contributors to debates over peak oil do acknowledge this artefactual quality (sometimes as part of a critique of method), they often seek to limit its effects in the pursuit of 'robust' numbers suitable for calculation. By contrast, work within human geography that draws on an STS approach to socio-technical systems seizes on these moments in which the apparent fixity of numbers is produced (Powell 2007, Mitchell 2009). By drawing on this work, the instability around numbers is no longer something to be contained (through better calculation or more generous error bars) but a window on the 'problem of calculation' that simultaneously underpins and undermines the peak oil proposition (Barry 2008).

Third, peak oil is predominantly a discussion about below-ground geographies. Critics of peak oil argue that it systematically discounts the role of 'above-ground' factors in governing rates of investment and production. Even so, the complex world of 'social production' into which oil enters once it leaves the ground hole is often reduced in these alternative accounts to country-bycountry variation in the level of investment risk, or a bifurcation of the world into areas that are open to international oil companies and those which are closed. Missing from these accounts is an understanding of the relational geographies of oil production and consumption, and the 
alternative (non state-centric) cartographies of transnational investment by both publically-traded and state-owned oil firms. Accounts rooted in economic geography, for example, can open up the 'black box' of investment to show how its spatiality and scale are responses to corporate objectives conditioned by logics of accumulation, rather than reactions to depletion. Investment by international oil companies in unconventional sources like 'tar sands' or 'extreme oil' from parts of the Arctic, for example, may not indicate a global process of barrel scraping but a chronic squeeze by resource-owning states of the resources available to international oil companies. Similarly, work on the social institutions of oil consumption can add flesh to the bones of 'demand' in order to better understand the new geographies of consumption driving passage to a post-peak world. Rising global demand has a geographical basis to it, as it is strongly linked to forms of urbanization and industrialization taking place in Asia and to a gradual decarbonisation of economies within the OECD. Yet the forms of urban and regional growth taking place in Asia may embed alternative energy systems (natural gas, renewables, mass transit) into infrastructure and capital equipment in ways that disrupt assumptions about the future rate of demand growth for oil.

Fourth, the discourses of imminence and dependency associated with peak oil can, when conjoined, produce a compelling imperative for action. As part of a more general argument about increasing energy insecurity, for example, peak oil and the prospect of depletion can legitimate a wide range of projects, from heavy investment in fuel efficiency and renewables to opening up new areas for fossil fuel development. Like other discursive couplets before it (carrying capacity, tropical deforestation or fuel-wood crisis), peak oil is not only a statement of political-ecological relations: it is also an active constituent of alliances and networks of actors that, through their collective agency, produce future material conditions. Research in political ecology captures both the multiple valencies that can surround discourses about nature, space and time, and the (sometimes violent) forms of actions they enable towards those whose land and resources are identified as the 'next frontier' (Peluso and Watts 2001, Perreault and Valdivia 2010). Howitt's (2001) call for a mode of doing resource management that does not reduce lands and resources "to dispassionate, and to some extent, interchangeable grid references.....statistical descriptions, grid references on maps or cells or spreadsheets" suggests some of the ways in which political ecology might begin to intersect with peak oil's relentless inventorying of global oil availability, its calculation of a looming supply gap, and the colonial 'resource imaginaries' to which this can give rise.

Fifth and finally, peak oil is premised on looming supply-side constraints. Yet work within geography and associated disciplines on the governance of carbon dioxide emissions suggests the 
possibilities of an alternative, low carbon future in which the current appetite for fossil fuels (and transportation fuels, in particular) is substantially curbed. Until very recently (see above), the curiously a-social world of peak oil advocates contained no feedback mechanism through which the social and environmental effects of the 'age of oil' could influence decisions about future production. Embedded in a more fully social and historical account, however, the rampant externalisation of the social and environmental costs of carbon-intensive economies can be seen to drive a series of social and political responses. Geographers and others have begun to identify and analyse some of these initiatives, which occupy several different spatial scales. They include governmental regulation, the use of fiscal instruments to increase the cost to users of carbonintensive fuels, creative 'debt-swaps' to reimburse would-be oil producers for oil kept in the ground, and a series of on-the-ground struggles over conventional and unconventional oil resources designed to the 'coal in the hole, the oil in the soil and the tar sands in the land' (Bulkeley and Betsill 2005, Davis 2007, Bond 2008).

\section{The collection of papers}

The seven papers in this collection take forward some of the above concerns, exploring ways in which contemporary geographical approaches can illuminate peak oil as a significant sociopolitical 'problematic.' All engage with place-specific contexts and actors, but they are not 'geographies' in the sense of examining regional facets of a putative oil crisis in the tradition of area studies. Instead the papers capture something of the diversity of approaches and concerns within human geography today, from critical realist assessments of corporate and state strategies, to post-structural critique of the framings and erasures that produce 'peak oil' as a concept, to social movement analysis. Their coverage is not comprehensive, however, as a number of perspectives that have had something significant to say about oil are not represented here (political ecology, for example). And, of course, there are many other specific questions relating to peak oil that the papers do not address (the implications of sustained high prices for oil on the current model of industrial agriculture, for example, or the 'new oil landscapes' associated with biofuels and tar-sands). Collectively, however, the papers in this collection express a desire to 'make sense' of peak oil by reference to work within human geography. And in contrast to the alternately apocalyptic and managerialist tones in which the debate over peak oil is often conducted outside of geography, they illustrate the discipline's capacity for bringing innovative, critical approaches to bear on issues of significant public and policy relevance.

For Emma Hemmingsen (2010), the key to understanding the significance of peak oil claims is to revisit the historical and institutional conditions within which Marion King Hubbert developed 
his provocative claims about the trajectory of oil production in the United States. 'At the base of Hubbert's Peak' offers a post-structural genealogy of the original model, identifying the personal and institutional affiliations that informed Hubbert's mathematical calculations in the 1950s. Her account quickly moves the reader beyond the conventional terms of the 'durable and divisive' debate over the exhaustion of oil stocks. Hubbert appears in her narrative as an intriguingly contradictory and richly-embedded social figure: an insider who, Cassandra-like, who spoke of an industry's decline at a point when its future had never seemed brighter, an 'oil man' who saw the future as alternately solar and nuclear, a 'company man' highly critical of the private development of energy resources, and an advocate of technocratic political control whose views on population and energy came to be embraced by parts of the environmental movement. The paper is historical in focus, but the implications of her analysis for the present conjuncture are clear: claims about oil's availability - and resource scarcity in general - should be understood by reference to the institutional contexts from which they emerge; and, furthermore, the invisibility of these contexts in debates over scarcity reflects an historical process of erasure.

In 'Oil in parallax', Mazen Labban (2010) also aims to correct a significant erasure in the conventional debate over peak oil: the absence of finance and its role in mediating the relationship between oil's availability in the ground and its price. His account opens with the startling observation that a much larger volume of oil is exchanged each day on commodity futures markets than moves through physical networks of oil production and consumption. The author uses this observation to show how oil circulates in two distinct spaces: the financial space of futures markets and the physical space of pipelines and reservoirs. What is significant, he argues, is that the expansion of value in and through oil has increasingly become divorced from oil's physical production. He points out how conventional arguments on both sides of the peak oil debate take no account of this divergence and fail to capture how the financialisation of oil now exerts a significant influence on price and the physical availability of oil. A critical political economy of oil, he argues, needs to account for both this financialisation of accumulation and its relationship to oil's physical production. Labban responds to this challenge by drawing on Marxian accounts of the circulation of commodities and the realisation of value. In particular, he develops the notion of parallax - the 'gap' between different representations of an object - to highlight the oscillation and connections between physical and financial representations of oil's scarcity. Labban's account of the financialisation of accumulation in oil offers a challenge to conventional critiques of peak oil that assume new investment in exploration and production will follow a rise in market prices. It also rejects the sweeping claims of some critical political economy that suggest financialisation has rendered physical production largely irrelevant to the circulation and expansion of value. 
Anna Zalik's (2010) paper on Oil Futures' also picks up on the temporalities and spatialities constructed in and through discourses of peak oil. Focussing on the scenario modelling exercises undertaken by Shell, Zalik examines the range of imagined insecurities in these projections of the future (climate change, shortages of conventional oil, political resistance to extractive activities) and the impacts they are imagined to have on oil markets. Her specific interest in the perceptions of a large corporate actor is both pragmatic - Shell has been constructing 'discursive futures' through its Scenarios exercises since the 1970s - and driven by an interest in the sociology of oil markets and how business actors can actively shape social perceptions of future supply. In Zalik's analysis, Shell's incorporation of peak oil as one of its three 'hard truths' about future energy markets is a 'strategically-charged' choice, a discursive construction that actively seeks to shape a future it purports to describe. The significance of such constructions, she argues, lies in their capacity for shaping speculative markets in ways that 'facilitate expansion of the oil frontier' by, for example, maintaining high prices and pushing back against local and regional claims for resource control.

In Less is More: spectres of scarcity and the politics of resource access in the upstream oil sector, Gavin Bridge and Andrew Wood consider the significance of peak oil for so-called 'Big Oil', the large, publiclytraded oil companies. On the face of it, depletion appears to offer the ultimate solution to a problem that has plagued the international oil industry for the last one hundred years: how to organise scarcity in the face of prodigious abundance. However, they find a surprising lack of consensus among Big Oil about an imminent, permanent decline in the availability of conventional crude. Turning from geology to political economy, they examine the nature of the real 'squeeze' on international oil firms, highlighting how the limits to production originate primarily above-ground in the ownership of reserves, the politics of resource access and the changing structures of the international oil industry.

The peak oil discourse has been sustained, in part, by a series of studies that report the 'peaking' of production in different countries. The effect is a 'roll-call' of oil producing states in which conventional production is thought to be on an irreversible decline (e.g. Strahan 2010). In some instances - particularly where states have been major oil exporters - the fiscal and political implications of this shift can be very significant. In Geographies of Security and Statehood in Norway's Battle for the North, Berit Kristoffersen and Stephen Young (2010) examine the national anxieties produced by a peaking of oil production in Norway. The authors examine how the prospect of a permanent decline in oil production both opens up a political space to contest further expansion of the resource frontier while also reviving historical concerns about energy security. Focussing on an ongoing dispute over proposed hydrocarbon development in the offshore North close to the Barents Sea, the authors illustrate the reshaping of 'state space' in Norway as concerns over 
energy security and environmental security are socially negotiated. Their study illustrates how established boundaries between public and private decision-making are being reconfigured, and the centrality of territorial mapping strategies to the process of imagining the North in the wake of peak oil. Their paper is significant in the context of this collection because of its attention to the intersections of environmental and energy security, and its focus on the state as a site of political activism.

The final two papers in the collection examine how recognition of the increasing costs associated with fossil fuel usage - and the prospect of peak oil in particular - are giving new life to longstanding arguments in favour of a re-localisation of economic activity. In Eco-localisation as a progressive response to peak oil and climate change' Peter North (2010) argues that the twin 'carbon crises' of peak oil and climate change are now creating the conditions for a 'reverse globalisation.' North's primary aim is to examine the politics of this process, and he does this by distinguishing between two forms of re-localisation: an 'immanent localisation' occurring through price signals in the marketplace which leaves the structures of contemporary capitalism largely intact, and an 'intentional localisation' that regards peak oil as a social crisis and an occasion to radically re-work the organisation of economic life. North works through the different politics contained in these views and offers a spectrum of critiques. Rejecting the notion that the politics of carbon are dominated by a 'post-political' managerialism, North emphasises the range of resource and environmental futures in contention around peak oil and climate change.

In the final paper, Ian Bailey, Rob Hopkins and Geoff Wilson (2010) further develop the localisation theme by focussing on one of the most popular and evangelical geographical imaginaries constructed around peak oil - the Transition Town. In 'Some things old, some things new: the spatial representations and politics of change of the peak oil relocalisation movement' they deconstruct the discourses of geographical scale and space associated with advocates of energy transition and the de-globalisation of economic activity. Peak oil may be a contemporary concern, but the authors find that the conceptual frameworks and specific language used to depict peak oil and promote contemporary social change owe much to previous environmental struggles. Such strategies of borrowing and blending have been successful: the Transition Towns movement has grown rapidly in the last few years in response to a range of social, economic and environmental concerns that loosely cohere around the label 'anti-globalisation.' As the authors point out, peak oil provides a motivating rationale for the Transition Towns network: the prospect of increasing energy scarcity serves as 'a general metaphor for ruptures between the spatially-joined but issuedisconnected world of globalisation and an alternative world view that reconnects issues and rekindles a sense of geographical belonging.' Regardless of whether one regards the Transition 
Town movement as engaged politics or a flight of fancy, the scale and pace of the phenomenon suggests it deserves further scrutiny.

\section{References}

Aleklett, K. 2006. “Oil: a bumpy road ahead” World Watch Magazine 19(1): 10-12.

Bailey, R. 2006. Peak Oil Panic. On line at http://reason.com/archives/2006/05/05/peak-oilpanic

Bailey, I., R. Hopkins and G. Wilson. 2010. Some things old, some things new: the spatial representations and politics of change of the peak oil relocalisation movement. Geoforum (this issue).

Bakker, K. 2000. Privatising Water, Producing Scarcity: the Yorkshire drought of 1995. Economic Geography 76(1)

Bardi, U. 2009: Peak oil: the four stages of a new idea. Energy 34: 323-6.

Barry 2008. Between Geoscience and Economics: Proven Reserves and Projective Devices. Paper presented at the Annual Meeting of American Geographers, Boston, April 15-18.

Bond, P. 2008. The state of the global carbon trade debate. Capitalism Nature Socialism, 1548-3290, Volume 19, Issue 4, 2008, Pages 89 - 106

Bridge, G. 2010. Past Peak Oil: Political Economy of Energy Crises. In Global Political Ecology. Routledge. Eds. Peet, Robbins and Watts.

Bridge, G., A. Wood 2010. Less is More: spectres of scarcity and the politics of resource access in the upstream oil sector. Geoforum (this issue)

Bulkeley, H. \& Betsill, M. Rethinking sustainable cities: multilevel governance and the 'urban' politics of climate change. Environmental Politics. 2005;14:42-63.

Campbell C. J. and J. H. Laherrère 1998, The end of cheap oil Scientific American 278, 80-5.

Campbell, C. 2005, Oil Crisis . Multi Science Publishing Co Ltd.

CERA 2006. Peak Oil Theory - "World Running Out of Oil Soon" - Is Faulty: Could Distort Policy \& Energy Debate. Cambridge Energy Research Associates. Cambridge, Massachusetts. Available at http://www.cera.com/aspx/cda/public1/news/pressReleases/pressReleaseDetails.aspx?CID $=8$ $\underline{444}$

Clarke, D. 2007. The Battle for Barrels: peak oil myths and world oil futures. London, Profile Books.

CNN 2003. World oil and gas 'running out' Oct $2^{\text {nd }}$.

CNN 2004 Oil: Is the end at hand? Nov 3

CNN 2007. The end of oil, Sept 17 
Crowley, T. Corrie, T., Diamond, D., Funk, S., Hansen, W., Stenhoff, A., and Swift, D. 2007. Transforming the Way DOD Looks at Energy. An Approach to Establishing an Energy Strategy. Logistics Management Institute, McLean, Virginia.

Davis, T. 2007. Breaking Ground without Lifting a Shovel: Ecuador's Plan to Leave Its Oil on the Ground. Houston Journal of International Law 243.

Deffeyes, K. 2001. Hubbert's Peak: the impending world oil shortage. Princeton and Oxford: Princeton University Press.

Deffeyes, K. 2005. Beyond Oil: the view from Hubbert's Peak. Hill and Wang.

Demeritt D, 2001 Scientific forest conservation and the statistical picturing of nature's limits in the Progressive-era United States Environment and Planning D: Society and Space 19(4) 431 - 459

Deutsche Bank 2004. Energy Prospects after the petroleum age. Current Issues Dec $2^{\text {nd. }}$

Dodson, J., and N. Sipe. 2007. Oil Vulnerability in the Australian City: Assessing Socioeconomic Risks from Higher Urban Fuel Prices. Urban Studies 44(1): 37-62.

U.S. Government Accounting Office. 2007. Crude Oil: Uncertainty about Future Oil Supply Makes It Important to Develop a Strategy for Addressing a Peak and Decline in Oil Production (GAO-07-283), Washington D.C. Available on line at http://www.gao.gov/products/GAO-07-283

Geman, B. 2009. The Other Peak Oil: Demand from Developed World Falling. Scientific American online, October 13th. http://www.scientificamerican.com/article.cfm?id=oilpetroleum-demand-developed-countries-alternative-fuel

Glacken, C. 1967. Traces on the Rhodian Shore. Berkeley, University of California Press.

Goodstein, D. 2004. Out of gas: the end of the age of oil. New York, W. W. Norton and Company.

Hall, C, R. Powers and W. Schoenberg. 2008. Peak Oil, EROI, Investments and the Economy in an Uncertain Future. In Biofuels, Solar and Wind as Renewable Energy Systems. Ed. D. Pimentel. Springer.

Harvey, D. 1974. Population, resources and the ideology of science Economic Geography, 50, 256277.

Heinberg, R. 2003 Party's Over: Oil, War and the Fate of Industrial Societies. New Society Publishers.

Hemmingsen, E. 2010. At the Base of Hubbert's Peak: grounding the debate on petroleum scarcity. Geoforum (this issue)

Hopkins, R. 2008. The Transition Handbook: From Oil Dependency to Local Resilience. Green Books.

Howitt, R. 2001. Retbinking Resource Management: justice, sustainability and indigenous peoples. Routledge.

International Energy Agency. 2008. World Energy Outlook.

Karbuz, S. 2006. http://www.energybulletin.net/node/13199

Klare, M. 2007. The Pentagon vs. Peak Oil. Available online, at http://www.tompaine.com/articles/2007/06/15/the pentagon vs peak oil.php 
Kristoffersen, B. and S. Young 2010. Geographies of Security and Statehood in Norway's 'Battle for the North'. Geoforum (this issue)

Kunstler, H. 2005. The Long Emergency: Surviving the Converging Catastrophes of the Twenty-First Century. Atlantic Monthly Press.

Labban, M. 2010. Oil in parallax: scarcity, markets and the financialization of accumulation.

Geoforum (this issue)

Lee, B. 2010. Managing the interlocking climate and resource challenges. International Affairs 85(6): $1101-1116$

Lohmann, L. 2009. Climate as Investment. Development and Change 40(6): 1063-1083.

Lovell H, Bulkeley H, Owens S, 2009, "Converging agendas? Energy and climate change policies in the UK" Environment and Planning C: Government and Policy 27(1) $90-109$

Lynch, M. 2009. 'Peak Oil' is a Waste of Energy. Op-Ed, New York Times 24 August.

Maas, P. 2009. Crude World: the violent twilight of oil. Allen Lane.

Manning, R. 2004. The oil we eat - following the food chain back to Iraq. Harpers Magazine, February. .

Maugeri, L. 2004. Oil - never cry wolf. Why the petroleum age is far from over. Science 304: 11145.

McNeill, J. R. 2000. Something New Under the Sun: an environmental history of the twentieth century. New York and London: Norton.

Mitchell, T. 2009. Future Measures: How To Calculate -- For a World Without Oil. Annual Public Lecture, ESRC Centre for Research on Socio-Cultural Change, University of Manchester. May 142009.

Meng, Q. and R. Bentley 2008. Global oil peaking: responding to the case for 'abundant supplies of oil'. Energy 33: 1179-1184.

Mommer, B. 2001. Global oil and the nation state. Oxford: Oxford University Press.

National Geographic 2004. The End of Cheap Oil (Cover Story), June.

North, P. 2010. Eco-localisation as a progressive response to peak oil and climate change - a sympathetic critique. Geoforum (this issue).

Odell P. 2009. The Long-Term Future for Energy Resources Exploitation.

Peluso, N. and M. Watts (eds) 2001. Violent Environments. Ithaca: Cornell University Press.

Perreault, T., and G. Valdivia. 2010. Hydrocarbons, popular protest and national imaginaries: Ecuador and Bolivia in comparative context. Geoforum

Pfeiffer D. A. 2006. Eating Fossil Fuels: Oil, Food and the Coming Crisis in Agriculture. New Society Publishers. , 
Powell, R. 2007. Geographies of science: histories, localities, practices, futures. Progress in Human Geography 31 (3) 309-329.

Retort 2005. Afflicted Powers: capital and spectacle in a new age of war. Verso.

Roberts, P. 2004. The End of Oil: The Decline of the Petroleum Economy and the Rise of a New Energy Order. Bloomsbury Publishing.

Ruppert, M 2004. Crossing the Rubicon: The Decline of the American Empire at the End of the Age of Oil. New Society Publishers.

Simmons, M. 2005. Twilight in the Desert: The Coming Saudi Oil Shock and the World Economy. John Wiley \& Sons, Canada.

Smil, V. 2005. Energy at the Crossroads: global perspectives and uncertainties. MIT Press.

Strahan D. 2007. The Last Oil Shock: A Survival Guide to the Imminent Extinction of Petroleum Man

Strahan, D. 2010. Oil Depletion Atlas. Online Interactive Map, available at www.lastoilshock.com/map.html

Swyngedouw, E. 2004. Social Power and the Urbanization of Water: Flows of Power. Oxford, Oxford University Press.

Upham, P. 2010. Critical issues in bioenergy security: a short introduction.

Geographies of Energy Transition, Seminar 2: Scales of energy security: between geopolitics and governance, May $7^{\text {th }}$ University of Birmingham. Briefing note available at

http://www.le.ac.uk/gg/pdfs/seminar_bradshaw_UK_ESRC_Energy_070510_2.pdf

UKERC 2009a The Global Oil Depletion Report. London, UK Energy Research Centre.

http://www.ukerc.ac.uk/support/Global\%20Oil\%20Depletion

UKERC 2009b. The Global Oil Depletion Report, Media Presentation. London, UK Energy

Research Centre. Available on-line at

http://www.ukerc.ac.uk/support/Global\%20Oil\%20Depletion

USGS no date. The 1920s. http://pubs.usgs.gov/circ/c1050/1920s.htm

Westervelt and Fournier 2005

USGS 2000. World Petroleum Assessment. Washington D.C.

Yergin, D. 1992. The Prize: the epic quest for oil, money and power. Free Press.

Yergin, D. 2009. Its Still the One. Foreign Policy, October.

Zalik, A. 2010. Oil 'Futures': Shell's Scenarios and the social construction of the global oil market. Geoforum (this issue)

\footnotetext{
${ }^{1} \mathrm{ASPO}$ was founded in 2000 by Colin Campbell, a former petroleum geologist and co-author with Jean Laherrère of an early and significant intervention in the debate over peak oil (Campbell and Laherrère 1998).

${ }^{2}$ Despite its name, the Texas Railroad Commission assumed the task of regulating oil production in the state of Texas early in the $20^{\text {th }}$ century. An instrument of market management, it was established 'to balance discordant supply and demand, to manage surplus, and to bring order and stability to a market laden with oversupply' and was particularly influential after the discovery in 1930 of the giant East Texas
} 
Field (Yergin 1992: 402). Given the role of Texas in overall U.S. oil supply, this state regulatory agency had a large influence on national oil production in the United States until the 1970s.

${ }^{3}$ Hubbert apparently had imposed this assumption to make the mathematics more tractable (Meng and Bentley 2008). 